\title{
MANAJEMEN PENGEMBANGAN WAKAF PRODUKTIF ERA DIGITAL DI LEMBAGA WAKAF BANI UMAR
}

\author{
Hamli Syaifullah ${ }^{1)}$, Ali Idrus ${ }^{2)}$, \\ 1) Program Studi Manajemen Perbankan Syariah, Fakultas Agama Islam, Universitas Muhammadiyah Jakarta \\ E-mail : hamlisyaifullah@umj.ac.id \\ ${ }^{2)}$ Manajemen Zakat dan Wakaf, Fakultas Agama Islam, Universitas Muhammadiyah Jakarta \\ E-mail: aliidrus@umj.ac.id
}

\begin{abstract}
Abstrak
Program Pengabdian Kepada Masyarakat (PKM) untuk Dosen Internal mencoba bekerjasama dengan Lembaga Wakaf Bani Umar, sebuah lembaga yang konsen dalam mengumpulkan dan mengembangkan aset wakaf menjadi lebih produktif. Metode yang digunakan ialah studi kasus, dengan terlibat langsung bersama Lembaga Wakaf Bani Umar selama kurang lebih 6 bulan. Dari tinjauan awal penulis di Lembaga Wakaf Bani Umar, menemukan dua permasalahan krusial yang ada di dalam lembaga, yaitu berkenaan dengan minimnya sumber daya manusia dan saluran pemasaran. Kemudian, penulis mengajukan dua konsep untuk menjawab permasalahan krusial tersebut, yaitu konsep Manajemen Sumber Daya Manusia berbasis volunteer (relawan), dan membuat saluran pemasaran berbasis digital.
\end{abstract}

Kata Kunci: Nadzhir, Wakaf Produktif, Relawan Wakaf, Saluran Pemasan Wakaf

\begin{abstract}
The Community Service Program (PKM) for internal lecturers tries to collaborate with The Bani Umar Waqf Institute, an institution that is concerned in collecting and developing waqf assets to be more productive. The method used is case studi, with direct involvement with the Bani Umar Waqf Institute for approximately 6 months. From the initial review of the author at The Bani Umar Waqf Institute, found two crucial problems that exist within the institution, namely regarding the lack of human resources and marketing channels. Then, the authors propose two concepts to answer these crucial problems, namely the concept of Human Resource Management based on volunteers, and create digital-based marketing channels.
\end{abstract}

Keywords: Nadzir, Productive Waqf, Waqf Volunteer, Waqf Marketing Channel

\section{PENDAHULUAN}

Pengembangan harta wakaf merupakan suatu keharusan bagi nadzir-baik perorangan ataupun lembaga, sehingga pokok harta wakaf tidak habis pakai-baik disebabkan oleh penyusutan aset wakaf karena unsur waktu ataupun habis disebabkan pengeluaran biaya perawatan yang diambilkan dari pokok harta wakaf. Sehingga salah satu fungsi wakaf sebagai instrumen keuangan syariah yang mampu memberikan kesejahteraan, mampu direalisasikan. Hal tersebut, sejalan dengan pandangan Saekhu (2014: 39-40) bahwa wakaf harus dikembangkan menjadi lebih produktif, sebagai instrumen untuk memajukan kesejahteraan ekonomi masyarakat, karena wakaf memiliki muatan nilai sosial dan ibadah.
Pandangan Saekhu, sejalan dengan arti wakaf yang ada dalam Undang-Undang No. 41 Tahun 2004 tentang Wakaf, yaitu: "wakaf ialah perbuatan hukum wakif untuk memisahkan dan/atau menyerahkan sebagian harta benda miliknya untuk dimanfaatkan selamanya atau untuk jangka waktu tertentu sesuai dengan kepentingannya guna keperluan ibadah dan/atau kesejahteraan umum menurut syariah".

Kata "memanfaatkan" dalam Undang-Undang No. 41 Tahun 2004 tentang Wakaf, penulis memiliki kecondongan sama seperti yang diungkap oleh Saekhu, yaitu dikembangkan. Artinya, harta wakaf harus dikembangkan dengan baik, sehingga harta wakaf mampu menjadi sumber ekonomi umat yang murah meriah. Tetapi, manfaatnya langsung dirasakan oleh masyarakat secara langsung. 
Menurut Asnaini dan Yustati (2017: 151), kehadiran undang-undang wakaf dimasukkan hasil rumusan konsepsi fikih wakaf baru di Indonesia yang antara lain meliputi benda yang diwakafkan (mauquf bih), peruntukan wakaf (maukuf alaih), sighat wakaf baik untuk benda bergerak maupun tidak bergerak, kewajiban hak nadzir wakaf, dan lain-lain. Furqon (2012: 37) menambahkan, undangundang wakaf juga mengakomudir adanya wakaf permanen dan temporer, wakaf keluarga dan umum, wakaf bergerak maupun wakaf tidak bergerak termasuk wakaf uang.

Dengan demikian, makna wakaf menjadi lebih luas. Kemudian, wakaf harus mampu dikembangkan. Karena wakaf merupakan tindakan hukum seseorang dalam bentuk pemisahan sebagian hartanya dan pelembagaannya digunakan untuk keperluan ibadah atau keperluan lainnya sesuai dengan ajaran Islam (Rozalinda, 2016: 311). Menurut Fuadi (2018: 172) pengembangan (pengelolaan) wakaf berdampak positif terhadap kemaslahatan (maslahah) masyarakatnya. Artinya, maslahah berarti manfaat atau suatu pekerjaan yang mengandung manfaat (Hamzah K, 2014: 28).

Dari definisi tersebut dapat diketahui bahwa wakaf dapat diartikan sebagai sesuatu yang substansi (wujud aktiva)-nya dipertahankan, sementara hasil atau manfaatnya digunakan sesuai dengan keinginan wakif (Ibrahim Siregar, 2012: 275). Dengan mempertahankan wujud substansi (aktiva)-nya, maka akan tercipta keadilan - salah satunya ialah keadilan ekonomi. Dimana, keadilan itu sendiri ialah untuk memberikan maslahah (kebaikan) kepada manusia (Daud, Azahari: 2019). Sementara maslahah merupakan tujuan agama yang paling penting (Kayadibi, 2019: 10).

Dari beberapa pengertian wakaf yang telah disampaikan, dapat disimpulkan bahwa wakaf merupakan barang yang telah dipisahkan kepemilikannya, baik dari individu maupun institusi, yang kemudian diserahkan kepemilikannya untuk kepentingan umum kepada nadzir. Sehingga harta wakaf boleh dimanfaatkan oleh siapa saja tanpa terkecuali, namun pokok dari harta tersebut tidak boleh terpakai (habis). Agar pokok wakaf tidak terpakai (habis), maka wakaf harus dijaga dan dikembangkan. Pada akhirnya, harta wakaf akan melahirkan wakaf.

Fuadi (2018: 172) menyampaikan dalam penelitiannya, bahwa banyak negara-negara yang telah berhasil mengelola dan mengembangkan harta wakaf. Misalnya Malaysia dengan menara Imara Wakaf yang kemudian dikomersilkan dalam bentuk sewa-menyewa; Turki dengan wakaf uang, kemudian masyarakat boleh meminjam uang tersebut; Mesir dengan wakaf yang diinvestasikan dalam bentuk saham dan sukuk pada Bank Syariah dan perusahaan-perusahaan lainnya; serta Amerika Serikat yang memiliki aset wakaf berupa proyek apartemen senilai US\$85 juta.

Untuk mengembangkan wakaf menjadi lebih produktif, Soemitra (2015: 436-437) mengungkapkan bahwa pengelolaan wakaf yang ditujukan sebagai instrumen menyejahtrakan masyarakat muslim, pendekatan yang digunakan adalah pendekatan bisnis dan manajemen. Tujuannya ialah, agar wakaf bukan hanya dikelola sebagai sebuah aset sosial (social oriented) semata, akan tetapi dipandang sebagai aset bisnis (bisnis oriented), yang manfaatnya akan disalurkan kepada umat sebagai mauquf alaihi (penerima wakaf) dari manfaat aset wakaf tersebut. Berkaitan dengan instrumen kesejahteraan, Thaker dan Pitchay (2016: 449) mengungkapkan wakaf telah memainkan peran yang sangat signifikan melalui variasinya dan berkontribusi luas terhadap kehidupan ekonomi dan sosial selama periode awal Islam. artinya, konsep pengembangan wakaf untuk menghadirkan kesejahteraan, adalah konsep yang pernah dijalankan oleh umat Islam dahulu kala, dan terbukti memberikan kesejahteraan pada mereka.

Muhammad Syafii Antonio dalam Andri Soemitra (2015: 437) berpandangan bahwa wakaf dalam konteks kekinian memiliki tiga ciri utama. Pertama, pola manajemen wakaf harus terintegrasi; dana wakaf dapat dialokasikan untuk programprogram pemberdayaan dengan segala macam biaya yang tercakup di dalamnya. Kedua, asas kesejahtraan nazhir, pekerja sebagai nazhir tidak lagi diposisikan sebagai pekerja sosial, tetapi sebagai professional yang biasa hidup dengan layak dari profesi tersebut. Ketiga, asas transparansi dan tanggung jawab, badan wakaf dan lembaga yang dibantunya harus melaporkan proses pengelolaan dana kepada umat setiap tahun.

Dari analisis situasi tersebut, maka penulis bermaksud melakukan penelitian sebagai salah satu Program Pengabdian kepada Masyarakat untuk Dosen Internal, Fakultas Agama Islam, Universitas Muhammadiyah Jakarta (FAI UMJ), dengan judul "Manajemen Pengembangan Wakaf Produktif di Era Digital" dengan Mitra Lembaga Wakaf Bani Umar. 


\section{IDENTIFIKASI MASALAH}

Program Pengabdian kepada Masyarakat untuk Dosen Internal, Fakultas Agama Islam Universitas Muhammadiyah Jakarta (FAI UMJ), dilakukan di Lembaga Wakaf Bani Umar. Lembaga Wakaf Bani Umar berdiri semenjak disahkannya Yayasan Wakaf Bani Umar pada tanggal 24 April 2015, yang Berkedudukan di kota Tangerang Selatan. Pendirian, sesuai Akta Notaris Nomor 16, dan Pengesahan Badan Hukum Yayasan Wakaf Bani Umar, dengan nomor Pendaftaran Menkumham 5015050436100042, Tanggal 4 Mei 2015 (Majalah Wakaf Bani Umar, 2016: 31).

Lembaga Wakaf Bani Umar merupakan lembaga yang konsen mengelola dana wakaf yang disalurkan oleh para wakif. Wakaf yang diterima dikategorikan menjadi dua bagian, yaitu wakaf produktif dan wakaf non-produktif. Wakaf produktif terdiri dari wakaf uang (wakaf tunai) dan wakaf proyek, contoh: wakaf uang, wakaf pertanian, wakaf ekonomi, dan lain sebagainya. Sementara untuk wakaf non-produktif terdiri dari barang-barang wakaf yang langsung diberikan kepada mauquf alaihi, contoh: wakaf tongkat tunanetra, wakaf kursi roda, wakaf sumur, dan lain sebagainya.

Setelah melakukan pengamatan terhadap Lembaga Wakaf Bani Umar, penulis menemukan dua permasalahan krusial yang ada di lembaga tersebut, antara lain: sumber daya manusia dan saluran pemasaran. Dalam Program Pengabdian kepada Masyarakat untuk Dosen Internal, Fakultas Agama Islam, Universitas Muhammadiyah Jakarta (FAI UMJ), akan berfokus pada pengembangan wakaf di era digital, dengan menawarkan konsep Manajemen Sumber Daya Manusia dan Pengembangan Saluran Pemasaran Wakaf Era Digital.

\section{TEORI YANG DIGUNAKAN}

Secara etimologi, Sayid Sabiq mengatakan bahwa wakaf berasal dari kata, waqafa yang berarti habasa (menahan) (Rozalinda, 2016: 309). Artinya ialah, menahan pokok harta agar digunakan manfaatnya untuk kepentingan umum. Sementara, Mahamood mengartikan wakaf sebagai sedekah jariah yang manfaatnya bersifat abadi (Mauluddin, Rahman, 2018: 49). Abadi artinya ialah harta (aset)-nya bersifat kekal, baik secara fisik maupun secara amal.

Wardi (2016: 96) mengartikan menahan dengan memberikan sesuatu berupa harta wakaf dan memanfaatkan hasilnya untuk layanan masyarakat. Syakur, dkk (2018: 75) menambahkan, bahwa dengan mengeluarkan wakaf, selain beribadah juga mempunyai dimensi membantu saudara yang membutuhkan.

Kemudian, secara epistimologi, Mardani (2011: 63-64) mencoba mengutip pandangan dari para Ulama Mazhab mengenai pengertian wakaf, antara lain sebagai berikut:

\section{Mazhab Syafi'i}

a. Wakaf menurut Imam Nawawi: "Menahan harta yang dapat diambil manfaatnya tetapi bukan untuk dirinya, sementara benda itu tetap ada padanya dan digunakan manfaatnya untuk kebaikan dan mendekatkan diri kepada Allah."

b. Wakaf menurut Ibn Hajar al-Haitami dan Syaikh Umairah: "Menahan harta yang bisa dimanfaatkan dengan menjaga keutuhan harta tersebut, dengan memutuskan kepemilikan barang tersebut dari pemiliknya untuk hal yang dibolehkan."

\section{Mazhab Hanafi}

a. Wakaf menurut Imam Syarkhasi: "Menahan harta dari jangkauan kepemilikan orang lain."

b. Wakaf menurut al-Mughni: "Menahan harta di bawah tangan pemiliknya, disertai pemberian manfaat sebagai sedekah."

\section{Mazhab Maliki}

Ibn Arafah mendefinisikan wakaf dengan: "Memberikan manfaat sesuatu, pada batas waktu keberadaannya, bersamaan tetapnya wakaf dalam kepemilikan si pemilik meski hanya perkiraan."

Dari beberapa pengertian wakaf yang telah disampaikan, baik secara etimologi maupun epistimologi, penulis sangat condong terhadap pandangan yang diungkap oleh Mauluddin dan Rahman (2018: 49-50) bahwa wakaf bukan sekadar ibadah, tetapi bentuk distribusi kekayaan yang memiliki peran penting dalam meningkatkan pembangunan ekonomi dan keadilan sosial di suatu negara.

Untuk mencapai peningkatan pembangunan ekonomi dan keadilan sosial, maka wakaf harus diproduktifkan. Menurut Huda (2017: 375) wakaf 
produktif ialah upaya menciptakan sumber pendanaan untuk dikelola dengan membangun unitunit usaha yang mendatangkan keuntungan untuk pemberdayaan sosial. Sulistiani (2017: 289) menambahkan bahwa wakaf produktif di Indonesia terus berkembang seiring bertambahnya kemajuan industri keuangan syariah. Shulthoni dan Saad (2018: 81) menyebutkan bahwa lembaga wakaf telah memberikan kontribusi besar terhadap pengembangan layanan publik dan sosial di beberapa negara Islam.

Dengan demikian, argumentasi yang dikembangkan oleh penulis dalam menulis artikel ini lebih mengedepankan konsep pengembangan aset (harta) wakaf menjadi lebih besar. Dimana, adanya pengembangan aset wakaf, akan melahirkan paradigma aset (harta) wakaf melahirkan aset (harta) wakaf. Sehingga, wakaf menjadi salah satu instrumen pemberdayaan ekonomi masyarakat (Wardi, 2016: 94). Karena wakaf merupakan bentuk nilai kebaikan Islam yang mengajarkan untuk mengembangkan harta wakaf secara amanah dan multi manfaat (Sulistiyani, dkk, 2018: 176)

\section{METODOLOGI PENGABDIAN}

Model Pengabdian Kepada Masyarakat (PKM) menggunakan pendekatan berbasis studi kasus. Menurut Creswell, studi kasus (case study) adalah suatu model yang menekankan pada eksplorasi dari suatu sistem yang terbatas (bounded system) pada satu kasus atau beberapa kasus secara mendetail, disertai dengan penggalian data secara mendalam yang melibatkan beragam sumber informasi yang kaya akan konteks (Herdiansyah, 2010: 76).

Penggunaan pendekatan studi kasus, akan memudahkan penulis memahami secara komprehensif permasalahan yang sedang dialami oleh Lembaga Wakaf Bani Umar. Sehingga, dengan mengetahuinya, akan menghasilkan solusi yang memberikan dampak signifikan terhadap permasalahan lembaga tersebut.

Untuk itu, peneliti meminta izin kepada Direktur Pelaksana Lembaga Wakaf Bani Umar, agar diberikan akses terhadap beberapa data yang dibutuhkan dalam Program Pengabdian Kepada Masyarakat (PKM). Pemberian data penunjang yang valid dan kredibel, akan menghasilkan temuan akan saran yang memberikan dampak positif terhap pengembangan lembaga ke depannya.
Selain itu, penulis juga akan menerima masukan yang diberikan oleh Direktur Lembaga Wakaf Bani Umar dalam pelaksanaan Program Pengabdian Kepada Masyarakat (PKM), yang bertujuan untuk memperkaya persepektif dari hasil akhir kegiatan ini. Sehingga, kebermanfaatan dari kegiatan ini, akan benar-benar dapat dirasakan, baik oleh Lembaga Wakaf Bani Umar pada khususnya ataupun lembaga wakaf produktif lainnya pada umumnya.

\section{PELAKSANAAN KEGIATAN}

Kegiatan Pengabdian Kepada Masyarakat (PKM) dilaksanakan sejak dikeluarkannya Keputusan Dekan Fakultas Agama Islam - Universitas Muhammadiyah Jakarta, Nomor 07 Tahun 2018, Tentang Program Pengabdian Masyarakat Internal Dosen Fakultas Agama Islam - Universitas Muhammadiyah Jakarta, Tahun Akademik 20182019, yang ditetapkan di Jakarta 21 Desember 2018. Kegiatan dilaksanakan selama kurang lebih 6 bulan, yang berakhir di bulan Juni 2019.

Adapun mitra yang dijadikan tempat Kegiatan Pengabdian Kepada Masyarakat (PKM) ialah Lembaga Wakaf Bani Umar, yang beralamat di Ruko Althia Park AB, No. 22, Graha Bintaro Raya, Perigi Baru, Pondok Aren, Tangerang Selatan, Banten. Salah satu alasan pemilihan mitra, karena lembaga tersebut memang konsen melakukan kegiatan pengembangan wakaf produktif, baik wakaf uang ataupun non-uang.

\section{HASIL DAN PEMBAHASAN}

\section{Tahap Awal Kegiatan}

Sebelum dikeluarkan Keputusan Dekan Fakultas Agama Islam - Universitas Muhammadiyah Jakarta, Nomor 07 Tahun 2018, Tentang Program Pengabdian Masyarakat Internal Dosen Fakultas Agama Islam - Universitas Muhammadiyah Jakarta, penulis yang terdiri dari dua orang dosen, dengan fokus keilmuan Perbankan dan Keuangan Syariah serta Ekonomi Syariah dan ZISWAF, melakukan penelitian awal di lembaga mitra, dan sekaligus meminta izin serta membuat MoU dengan mitra.

Setelah izin didapatkan, penulis melakukan penelitian awal terhadap permasalahan yang dihadapi oleh mitra. Secara umum, penulis menemukan dua masalah krusial yang dihadapi oleh mitra, yaitu berkaitan dengan Sumber Daya Manusia (SDM) dan juga saluran pemasaran wakaf. 
Pertama, permasalahan Sumber Daya Manusia. Di mana, salah satu penyebab adanya masalah SDM yang ada di Lembaga Wakaf Bani Umar ialah minimnya SDM yang direkrut oleh pihak Yayasan Wakaf Bani Umar. Hal tersebut, membuat beberapa bagian/divisi diisi dengan cara rangkap oleh satu SDM. Dampaknya ialah terjadinya penurunan tingkat produktivitas kinerja SDM yang bersangkutan.

Salah satu alasan minimnya perekrutan SDM oleh Yayasan Wakaf Bani Umar ialah kondisi keuangan yang tak memungkinkan untuk merekrut banyak karyawan. Apalagi, bila dikaitkan terhadap keberadaan lembaga yang masih baru. Sehingga, sangat tidak memungkinkan untuk merekrut banyak karyawan. Maka pihak yayasan memutuskan untuk memberikan pekerjaan yang bersifat rangkap terhadap karyawan yang ditugaskan di Lembaga Wakaf Bani Umar.

Dari sisi keuangan, langkah yang ditempuh oleh pihak yayasan cukup logis, yaitu untuk meminimalisir biaya yang dikeluarkan oleh yayasan. Akan tetapi, dari sisi produktivitas kinerja tentunya akan membuat kinerja karyawan menurun. Karena, SDM yang terlibat di dalamnya tidak bisa fokus bekerja sesuai tugas, pokok, dan fungsinya. Akan tetapi, satu karyawan harus mengurusi berbagai macam pekerjaan yang ada.

Oleh karena itu, dibutuhkan solusi yang bisa menjadikan yayasan tetap memiliki tingkat produktivitas yang tinggi, tetapi biaya yang dikeluarkan tidak terlalu besar. Sehingga Lembaga Wakaf Bani Umar yang berada di bawah naungan Yayasan Wakaf Bani Umar tetap bisa beroperasi mengumpulkan dana wakaf dari masyarakat, kemudia mengelolanya menjadi sumber daya ekonomi alternatif untuk memberikan kesejahtraan kepada umat Islam.

Kedua, permasalahan saluran pemasaran. Saluran pemasaran yang ada di Lembaga Wakaf Bani Umar diduga kurang memberikan dampak signifikan terhadap pengembangan lembaga. Sehingga membuat tersebut tak mampu berkembang. Padahal, pihak yayasan sangat berharap lembaga tersebut bisa berkembang signifikan ke depannya.

Bila dikaji lebih mendalam, dan dikaitkan terhadap perkembangan dunia digital saat ini, Lembaga Wakaf Bani Umar kurang mengoptimalkan saluran pemasaran berbasis digital. Padahal, saluran pemasaran berbasis digital berbiaya murah. Sehingga, perlu adanya dorongan untuk mengoptimalkan saluran pemasaran berbasis digital ke depannya.

\section{Tahap Pelaksanaan Kegiatan}

Setelah melakukan analisis terhadap permasalahan yang terjadi di Lembaga Wakaf Bani Umar, maka Penulis menawarkan dua konsep pengelolaan dan pengembangan wakaf produktif di era digital saat ini. Dua konsep tersebut, Penulis yakini akan menjadi solusi dari permasalahan yang dialami oleh lembaga.

Adapun konsep yang ditawarkan oleh penulis ialah, konsep rekrutmen SDM dan konsep fundrising wakaf melalui digital.

\section{Konsep Rekrutmen SDM}

Bila melihat kondisi keuangan yang dimiliki oleh Lembaga Wakaf Bani Umar, rasa-rasanya untuk menambah karyawan tidak memungkinkan. Apalagi, biaya operasional yang dimiliki oleh lembaga tersebut untuk saat ini, hampir semua berasal dari pendiri Yayasan Wakaf Bani Umar. Karena, keuntungan dari wakaf uang yang diperoleh dari pewakaf, belum mencukupi membiayai beban operasional lembaga.

Padahal, keberadaan SDM sangat penting, sehingga menuntut setiap organisasi mendapatkan pegawai yang berkualitas dan produktif untuk menjalankan organisasi (Kalangi, 2015: 1). Kemudian, SDM akan menentukan keberadaan layanan yang diberikan oleh organisasi. Dimana, Rokhmaniyah (2017: 74) menyebutkan mutu (quality) adalah kesesuaian antara suatu produk atau jasa dengan harapan pengguna. Sehingga mutu akan menghadirkan kepuasan terhadap pelanggan (pengguna/konsumen).

Sementara, menambah karyawan sebagai SDM yang akan memperkuat Lembaga Wakaf Bani Umar menjadi sebuah keharusan. Karena, tak akan mungkin mampu menjadikan Wakaf Bani Umar sebagai Nadzir yang tumbuh dan berkembang, tanpa sokongan SDM unggul yang paham akan pengelolaan harta wakaf secara profesional, serta paham juga berkaitan dengan ilmu bisnis dan manajemen keuangan modern.

Dengan demikian, keberadaan SDM, baik pada aspek kualitas maupun kuantitas memang sangat menentukan kinerja, produktivitas dan keberhasilan 
suatu institusi (Nuruddin, 2010: 28). Oleh karena itu, bila Lembaga Wakaf Bani Umar ingin menjadi lembaga nadzir yang berkembang dan besar, maka menambah SDM menjadi keharusan.

Untuk memecahkan masalah tersebut, penulis menawarkan konsep rekrutmen relawan menjadi nadzir di Lembaga Wakaf Bani Umar. Rekrutmen relawan nadzir dilakukan melalui kerjasama dengan Perguruan Tinggi yang memiliki Program Studi Manajemen Zakat \& Wakaf, serta Program Studi Ekonomi Islam dengan konsentrasi Zakat \& Wakaf. Tentu saja, mahasiswa yang direkrut berasal dari Perguruan Tinggi yang berada di sekitar Tangerang Selatan, Tangerang Kota, Depok, Bogor, serta Jakarta, ataupun di luar daerah yang bersedia menjadi relawan.

Langkah yang harus dilakukan ialah, Lembaga Wakaf Bani Umar melakukan MoU dengan Perguruan Tinggi yang menyelenggarakan Program Studi Manajeman Zakat \& Wakaf atau Program Studi Ekonomi Islam dengan konsentrasi Zakat \& Wakaf. Dimana, Lembaga Wakaf Bani Umar meminta kepada Perguruan Tinggi bila akan melakukan praktikum magang, maka dipersilahkan untuk magang di Lembaga Wakaf Bani Umar. Karena, praktikum magang biasanya menjadi kegiatan wajib bagi setiap mahasiswa yang akan lulus.

Setelah melakukan MoU, tinggal dijadwalkan mahasiswa yang akan ditugaskan oleh Perguruan Tinggi untuk melakukan magang. Jadwalkan sebisa mungkin agar jadwal antara satu perguruan tinggi dengan perguruan tinggi lainnya tidak bentrok. Sehingga Lembaga Wakaf Bani Umar mendapatkan mahasiswa secara simultan selama satu tahun penuh.

Misalnya, setiap mahasiswa yang ditugaskan diwajibkan untuk magang selama 2 bulan. Maka, waktu 2 bulan yang telah ditetapkan, agar dijadwal antara satu perguan tinggi dengan perguruan tinggi lainnya tidak bentrok. Dari jadwal tersebut, Lembaga Wakaf Bani Umar nanti yang akan diuntungkan. Karena, Lembaga Wakaf Bani Umar akan mendapatkan mahasiswa magang selama setahun penuh.

Untuk mempermudah memahami konsep tersebut, perhatikan gambar 1 di bawah ini:

\section{Gambar 1 \\ Konsep Rekrutmen Relawan Sebagai Nadzir Wakaf}

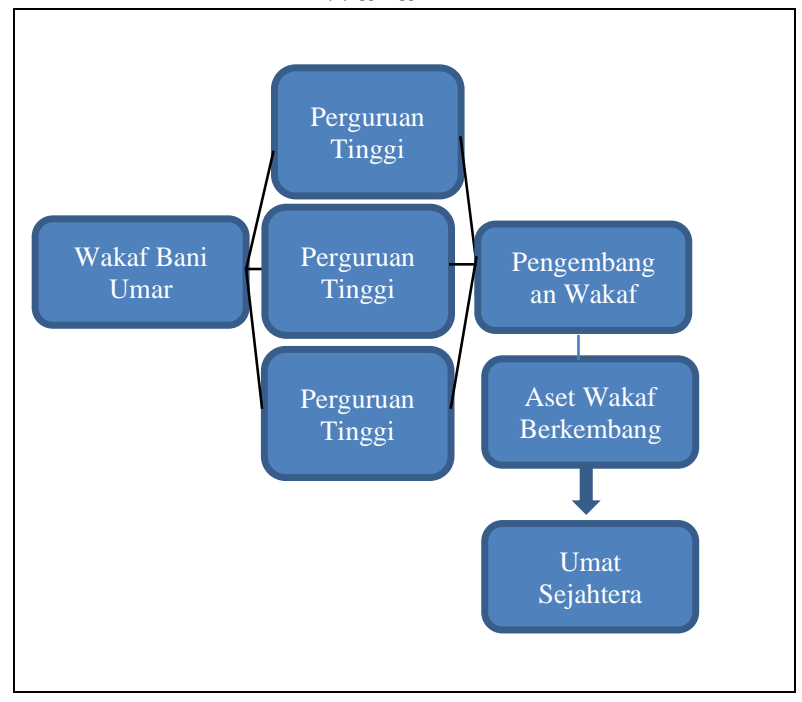

Dari konsep yang digambarkan pada gambar 1, dapat diperoleh informasi bahwa semakin banyak perguruan tinggi yang diajak untuk melakukan kerjasama, akan semakin besar potensi untuk menggalang harta wakaf dari masyarakat, dan kemudian dikembangkan melalui sektor bisnis yang dimiliki oleh nadzir. Maka dari itu, konsep tersebut dapat digunakan oleh Lembaga Wakaf Bani Umar yang saat ini sangat membutuhkan penambahan SDM untuk memperkuat lembaga.

\section{Konsep Fundrising Wakaf Melalui Digital}

Konsep fundrising wakaf melalui digital atau digital marketing adalah konsep mengumpulkan wakaf dengan cara memperkenalkan dan memasarkan wakaf kepada masyarakat muslim agar mau berwakaf. Menurut Oktaviani dan Rustandi (2018: 34) keberadaan digital marketing dapat menjangkau semua kalangan, kapanpun, dengan cara apapun, dan dimanapun.

Pengumpulan wakaf dengan metode ini, lebih mengedepankan adanya aspek edukasi kepada masyarkaat. Adanya edukasi, diharapkan membuat masyarakat sadar bahwa wakaf bukan hanya sebuah kebutuhan untuk akhirat semata, akan tetapi agar menjadi sebuah gaya hidup untuk menolong orang lain. Oktaviani dan Rustandi (2018: 3-4) menambahkan bahwa digital marketing tentu sangat jauh lebih unggul dibandingkan dengan marketing konvensional yang terbatas waktu, lokasi, dan jangkauan pengguna. Selain itu, Haryanto (2019: 43) menyebutkan bahwa marketing konvensional atau periklanan, memerlukan biaya yang lumayan besar. 
Putri dan Fithrah (2017: 133) menambahkan bahwa gaya periklanan yang semakin interaktif akibat keberadaan perkembangan teknologi dan komunikasi telah membuat terjadinya perubahan dalam aktivitas marketing sebuah perusahaan. Purwana, Rahmi, dan Aditya (2017: 2) memperkuat pandangan Putri dan Fithrah, bahwa strategi digital marketing lebih prospektif, karena memungkinkan para calon pelanggan potensial untuk memperoleh segala macam informasi mengenai produk dan bertransaksi melalui internet.

Dengan demikian, penggunaan digital marketing dalam kegiatan fundrising wakaf di Lembaga Wakaf Bani Umar menjadi sebuah keharusan. Karena, fundraising dapat menumbuhkan kepercayaan dan hubungan dengan masyarakat (Naim, 2019: 102). Bila dilakukan secara konsisten, akan meningkatkan branding lembaga. Sehingga Lembaga Wakaf Bani Umar akan semakin berkembang ke depannya.

Beberapa konsep fundrising berbasis digital yang ditawarkan oleh Penulis kepada Lembaga Wakaf Bani Umar, adalah sebagai berikut:

\section{a. Website Wakaf Bani Umar}

Sebenarnya, Wakaf Bani Umar telah memiliki domain website semenjak berdiri, dengan alamat: www.wakafbaniumar.org. Hanya saja, karena SDM yang mengelola website berhenti, dan Yayasan Wakaf Bani Umar tidak mencari pengganti dari SDM yang mengelola website, maka website Wakaf Bani Umar terbengkalai. Terbengkalainya website Wakaf Bani Umar karena tidak ada yang mengurusi, berakibat pada tidak adanya informasi berkaitan dengan pembayaran paket hosting dan domain website tersebut. Sehingga website tersebuat disuspend (diputus).

Semenjak di-suspend, Yayasan Wakaf Bani Umar tidak memiliki website resmi. Padahal, website di era digital menjadi salah satu saluran pemasaran yang sangat penting untuk dimiliki. Maka dari itu, dari kegiatan Pengabdian Kepada Masyarakat (PKM) ini, penulis memberikan penawaran konsep isi website yang akan dibuat oleh Yayasan Wakaf Bani Umar.

Isi atau tampilan website yang harus dimiliki oleh Wakaf Bani Umar, sekurang-kurangnya harus berisi, antara lain:

\section{1) Beranda}

Beranda merupakan tampilan website yang dapat dilihat secara keseluruhan oleh pengunjung.

\section{2) Tentang Kami}

Tentang kami akan berisi informasi berkaitan dengan, a). Sejarah, b). Visi dan Misi, c). Manajemen/Struktur Organisasi, d). Legalitas Yayasan, d). Mitra

\section{3) Program}

Program merupakan laman yang berisi tentang program-program yang dimiliki oleh Yayasan Wakaf Bani Umar. Di dalam pogram, harus dideskripsikan secara jelas, dan deskripsi yang ditampilkan harus memenuhi unsur-unsur copy writing yang benar.

\section{4) Donasi}

Donasi merupakan laman yang berisi para donatur yang telah bersedekah dan berwakaf di yayasan Wakaf Bani Umar. Laman donasi, untuk membangun kepercayaan (trust) kepada para donatur. Sehingga para donatur rajin berdonasi di Yayasan Wakaf Bani Umar.

\section{5) Berita}

Berita merupakan laman yang akan berisi berita kegiatan yang dilakukan oleh Yayasan Wakaf Bani Umar. Hal tersebut berfungsi sebagai informasi kepada para donatur, bahwa uang yang didonasikan memang benar-benar dikelola dan diserahkan kepada orang-orang yang berhak menerimanya.

6) Relawan

Relawan merupakan laman yang berisi informasi berkaitan dengan para relawan yang bersedia mengabdikan dirinya di Yayasan Wakaf Bani Umar. Relawan, bisa berasal dari mahasiswa Ekonomi Syariah, mahasiswa umum, ataupun dari kalangan masyarakat umum, yang mau mewakafkan waktu dan tenaga yang dimilikinya.

\section{b. Facebook Wakaf Bani Umar}

Yayasan Wakaf Bani Umar sebagai institusi sosial, yang khusus mengelola wakaf produktif dari para pewakaf, sebenarnya telah memiliki facebook resmi. Hanya saja, pengelolaan facebook sebagai media yang bisa dijadikan alat marketing digital kurang maksimal. Maka dari itu, dari adanya kegiatan Pengabdian Kepada Masyarakat (PKM), Penulis memberikan masukan dan saran untuk mengelola facebook dengan baik dan benar.

Beberapa masukan dan saran yang kami berikan untuk Yayasan Wakaf Bani Umar, antara lain:

1) Penjadwalan iklan berupa produk Wakaf Bani Umar di facebook secara teratur setiap harinya. Misalnya, memposting iklan sehari 3 kali postingan (pagi, siang dan sore), memposting gambar-gambar yang berkaitan dengan edukasi wakaf, dan lain sebagainya.

2) Materi iklan yang menarik. 
3) Gambar iklan yang menarik.

4) Memposting foto berkaitan dengan kegiatan yang dilakukan oleh Yayasan Wakaf Bani Umar.

5) Menambah jumlah pertemanan facebook.

\section{c. Fanpage Wakaf Bani Umar}

Yayasan Wakaf Bani Umar telah memiliki fanpage tersendiri. Sama juga dengan facebook, hanya saja fanpage yang dimiliki oleh Yayasan Wakaf Bani Umar tidak dikelola dengan baik. Oleh karena itu, dari kegiatan Pengabdian Kepada Masyarakat (PKM) ini, penulis memberikan saran dan masukan untuk Yayasan Wakaf Bani Umar.

Beberapa masukan dan saran yang kami berikan untuk Yayasan Wakaf Bani Umar, antara lain:

1) Menyingkronkan antara akun facebook dengan fanpage yang dimiliki oleh Wakaf Bani Umar. Sehingga setiap informasi yang diposting di fanpage, secara otomatis akan keluar di laman facebook.

2) Penjadwalan iklan berupa produk Wakaf Bani Umar di fanpage secara teratur setiap harinya. Misalnya, memposting iklan sehari 3 kali postingan (pagi, siang dan sore), memposting gambar-gambar yang berkaitan dengan edukasi wakaf, dan lain sebagainya.

3) Materi iklan yang menarik.

4) Gambar iklan yang menarik.

5) Memposting foto berkaitan dengan kegiatan yang dilakukan oleh Yayasan Wakaf Bani Umar.

6) Menambah jumlah suka (like) untuk fanpage Wakaf Bani Umar, baik secara manual ataupun dengan cara iklan berbayar.

\section{d. Istagram Wakaf Bani Umar}

Yayasan Wakaf Bani Umar sebagai lembaga yang mengelola wakaf produktif, sebenarnya telah memiliki istagram institusi. Hampir sama dengan facebook dan fanpage, istagram yayasan tidak dikelola dengan manajemen pengelolaan yang baik, khususnya berkaitan dengan postingan. Dimana, positingan yang dilakukan, hanya sekadar postingan sekadarnya saja, dan tidak dilakukan secara terjadwal. Padahal, positingan yang dilakukan secara terjadwal, akan memberikan dampak yang besar terhadap peningkatan pengelolaan harta wakaf, baik secara langsung ataupun tidak langsung. Melalui kegiatan Pengabdian Kepada Masyarakat (PKM) ini, Penulis memberikan saran dan masukan untuk Yayasan Wakaf Bani Umar dalam mengelola istagram, antara lain:

1) Menyingkronkan setiap postingan yang dilakukan di istagram dengan facebook.

2) Penjadwalan iklan berupa produk Wakaf Bani Umar di instagram secara teratur setiap harinya.
Misalnya, memposting iklan sehari 3 kali postingan (pagi, siang dan sore), memposting gambar-gambar yang berkaitan dengan edukasi wakaf, dan lain sebagainya.

3) Materi iklan yang menarik.

4) Gambar iklan yang menarik.

5) Memposting foto berkaitan dengan kegiatan yang dilakukan oleh Yayasan Wakaf Bani Umar.

6) Menambah jumlah pertemanan untuk istagram Wakaf Bani Umar, baik secara manual ataupun dengan cara iklan berbayar.

\section{Ucapan Terima Kasih}

Penulis mengucapkan terima kasih kepada Dekan Fakultas Agama Islam - Universitas Muhammadiyah Jakarta, Ibu Rini Fatma Kartika, S.Ag, MH., yang telah memberikan dukungan berupa pendanaan dari kegiatan ini. Serta ucapan terimakasih kepada Direktur Lembaga Wakaf Bani Umar, Bapak Budi Indra Agusci, S.Ag, M.Si., serta Pembina Yayasan Wakaf Bani Umar, Drs. H. Iwan Giwankara, yang telah memberi izin untuk dijadikan sebagai mitra dalam kegiatan ini.

\section{PENUTUP}

\section{Kesimpulan}

Berdasarkan temuan dan pembahasan terhadap bab sebelumnya, maka diperoleh kesimpulan sebagai berikut:

1. Untuk menanggulangi kurangnya SDM sebagai mesin penggerak lembaga, Lembaga Wakaf Bani Umar dapat mengaktifkan relawan nadzir melalui skema kerjasama dengan Perguruan Tinggi. Semakin banyak relawan dari Perguruan Tinggi bergabung di Lembaga Wakaf Bani Umar, akan semakin besar peluang untuk mendapatkan dan mengembangkan harta wakaf ke depannya.

2. Lembaga Wakaf Bani harus mulai mengembangkan saluran pemasaran melalui digital. Karena saluran pemasaran melalui digital berbiaya murah. Kemudian, konsisten untuk melakukan edukasi menggunakan kontenkonten kreatif. Sehingga akan banyak masyarakat yang mau berdonasi wakaf di Lembaga Wakaf Bani Umar. 


\section{Saran}

Berdasarkan temuan dan kesimpulan yang didapatkan, Penulis menyarankan dua hal yang harus dilakukan oleh Lembaga Wakaf Bani Umar, antara lain:

1. Segera melakukan kerjasama dengan Perguruan Tinggi yang menyelenggarakan Program Studi Manajemen Zakat \& Wakaf serta Program Studi Ekonomi Syariah dengan konsentrasi Manajemen Zakat \& Wakaf, untuk meminta mahasiswanya magang di lembaga tersebut, sebagai relawan nadzir wakaf.

2. Aktif dan konsisten dalam melakukan pemasaran melalui digital. Karena pemasaran melalui digital, memiliki dampak yang sangat besar untuk mengajak masyarakat berwakaf, serta berbiaya murah.

\section{DAFTAR PUSTAKA}

Antonio, Muhammad Syafii. 2015. Pengantar Pengelolaan Wakaf Secara Produktif. dalam Achmad Djunaidi dan Thobieb al-Asyhar. Menuju Era Wakaf Produktif. dalam Andri Soemitra. Bank dan Lembaga Keuangan Syariah. Cetakan 5. Jakarta: Prenadamedia Group.

Asnaini; Yustati, Herlina. 2017. Lembaga Keuangan Syariah: Teori dan Praktiknya di Indonesia. Yogyakarta: Penerbit Pustaka Pelajar.

Daud, Zakiul Fuady Muhammad; Azahari, Raihanah. 2019. "The wajibah will Alternative Wealth Transition for Individuals Who Are Prevented From Attaining Their Inheritance." International Journal of Ethics and Systems.

Fuadi, Nasrul Fahmi Zaki. 2018. "Wakaf Sebagai Instrumen Ekonomi Pembangunan Islam." Economica: Jurnal Ekonomi Islam. Volume 9. Nomor 1.

Furqon, Ahmad. 2012. "Wakaf Sebagai Solusi Permasalahan-Permasalahan Dunia Pendidikan di Indonesia." Jurnal Hukum Islam. Volume 10. Nomor 1.

Hamzah K. 2015. "Revitalisasi Teori Maslahat Mulghah al-Tuhfi dan Relevansinya dalam Pembentukan Perundang-Undangan di Indonesia." Ahkam: Jurnal Ilmu Syariah. Volume XV. Nomor 1.
Herdiansyah, Haris. 2010. Metodologi Penelitian Kualitatif untuk Ilmu-Ilmu Sosial. Jakarta: Penerbit Salemba Humanika.

Huda, Miftahul. 2017. "Kemandirian Berbasis Wakaf di Masjid Besar Imam Ulomo Sampung Ponorogo." Ahkam: Jurnal Ilmu Syariah. Volume 12. Nomor 2.

Kalangi, Roosje. 2015 "Pengembangan Sumber Daya Manusia dan Kinerja Aparat Sipil Negara di Kabupaten Sangihe Provinsi Sulawesi Utara." Jurnal LPPM Bidang EkoSosBudKum. Volume 2. Nomor 1.

Kayadibi, Saim. 2019. "The State As An Essential Value (Ḍarūriyyāt) of the Maqāṣid alSharī'ah." Ahkam: Jurnal Ilmu Syariah. Volume 19. Number 1.

Mardani. 2011. Hukum Ekonomi Syariah di Indonesia. Bandung: PT Refika Aditama. 2011.

Mauluddin, Muhammad Ikhwan; Rahman, Asmak Ab. 2018. "Cash Waqf From the Perspective of Majelis Ulama Indonesia (MUI) and the Scholars of Aceh: An Analysis." New Developments in Islamic Economics.

Naim, Abdul Haris. 2019. "Lembaga Pengelola Wakaf dan Manajemen Fundraising." ZISWAF: Jurnal Zakat dan Wakaf. Volume 6. Nomor 1.

Nuruddin, Amiur. 2010. "SDM Berbasis Syariah." Tsaqafah: Jurnal Peradaban Islam. Volume 6. Nomor 1.

Oktaviani, Femi; Rustandi, Diki. 2018. "Implementasi Digital Marketing dalam Membangun Brand Awareness." PRofesi Humas: Jurnal Ilmiah Ilmu Hubungan Masyarakat. Volume 3. Nomor 1.

Purwana ES, Dedi; Rahmi; Aditya, Shandy. 2017. "Pemanfaatan Digital Marketing Bagi Usaha Mikro, Kecil, dan Menengah (UMKM) di Kelurahan Malaka Sari, Duren Sawit.” Jurnal Pemberdayaan Masyarakat Madani (JPMM). Volume 1. Nomor 1.

Putri, Surya Dinda; Fithrah, Dini Salmiyah. 2017. "Pengaruh Online Marketing Campaign \#SAMYANGCHALLENGE Terhadap Consumer Behavior Digital Natives Pengguna Youtube Indonesia." PRofesi Humas: Jurnal 
Ilmiah Ilmu Hubungan Masyarakat. Volume 1. Nomor 2.

Rokhmaniyah. 2017. "Manajemen Sumber Daya Manusia untuk Mencapai Pendidikan yang Berkualitas di Sekolah Dasar." DWIJACENDEKIA: Jurnal Riset Pedagogik, 1(1).

Rozalinda. 2016. Fikih Ekonomi Syariah: Prinsip dan Implementasinya Pada Sektor Keuangan Syariah. Jakarta: RajaGrafindo Persada.

Rudy Haryanto. 2019. "Efektifitas Iklan Pada Keputusan Nasabah BPRS di Madura." Iqtishadia: Jurnal Ekonomi dan Perbankan Syariah. Volume 6. Nomor 1.

Saekhu. 2014. "Seputar Persoalan Pelayanan Wakaf di Kantor Urusan Agama (KUA) Kecamatan Keling Kabupaten Jepara.” Economica: Jurnal Ekonomi Islam. Volume 5. Edisi 2.

Shulthoni, Muhammad; Saad, Norma Md. "Waqf Fundraising Management: A Conceptual Comparison Between Traditional and Modern Methods in The Waqf Institutions." IJIMS: Indonesian Journal of Islam and Muslim Societies. Volume 8. Number 1.

Siregar, Ibrahim. 2012. "Pembaharuan Hukum Perwakafan di Indonesia." Tsaqafah: Jurnal Peradaban Islam. Volume 8. No. 2.

Soemitra, Andri. 2015. Bank dan Lembaga Keuangan Syariah. Cetakan 5. Jakarta: Prenadamedia Group.

Sulistiani, Siska Lis. 2017. "Analisis Implementasi Wakaf Wasiat Polis Asuransi Syariah di Lembaga Wakaf al-Azhar Jakarta." Ijtihad: Jurnal Wacana Hukum Islam dan Kemanusiaan. Volume 17. Nomor 2.

Sulistiani, Siska Lis; Bayuni, Eva Misfah; Yunus, Muhammad. 2018. "Analisis Hukum Islam Terhadap Pengembangan Wakaf Berbasis Sukuk untuk Pemberdayaan Tanah yang Tidak Produktif di Indonesia." Ijtihad: Jurnal Wacana Hukum Islam dan Kemanusiaan. Volume 18. Nomor 2.

Syakur, Abd; Yuswadi, Hary; Sunarko, Bagus Sigit; Wahyudi, Edi. 2018. "Tata Kelola Wakaf dalam Meningkatkan Kesejahteraan Masyarakat di Kabupaten Jember". Al-Ihkam:
Jurnal Hukum dan Pranata Sosia. Volume13. Nomor 1.

Thaker, Mohamed Asmy Bin Mohd Thas; Pitchay, Anwar Allah. 2016. "Developing Waqaf Land Through Crowdfunding-Waqaf Model (CWM): The Case of Malaysia." Journal of Islamic Accounting and Business Research. 9 (3).

Tim Redaksi Majalah Wakaf Bani Umar. 2016. Sejarah Yayasan Wakaf Bani Umar. Tangerang Selatan: Lembaga Wakaf Bani Umar.

Wardi, Moch. Cholid. 2016. “The Implementation of Cash Waqf in The Pesantren of Al-Amien Prenduan Sumenep Regency of Madura". AlIhkam: Jurnal Hukum dan Pranata Sosia. Volume 11. Nomor 1. 